\title{
9 Economic consequences of trade and investment liberalisation: the case of Vietnam
}

\author{
Thanh Tri Vo, Duong Anh Nguyen, and \\ Thien Thi Nhan Do
}

\section{Introduction}

Since it initiated Doi Moi (Renovation) in 1986, Vietnam has embarked on bold and comprehensive economic reforms. A key pillar of reforms is economic integration, to reduce at-the-border and behind-the-border barriers to trade and investment. Economic integration has broadened opportunities through access to foreign investment and foreign markets, adaptation to international trade rules, deeper participation in global value chains, amongst others. By 2018, however, economic integration attempts largely focused on liberalisation of trade and investment. Deeper liberalisation attempts in labour mobility, environmental standards, competition policy, amongst others, were more evident only in highquality free trade agreements (FTAs) such as the Comprehensive and Progressive Agreement for Trans-Pacific Partnership (CPTPP), ${ }^{1}$ European Union (EU)-Vietnam FTA (EVFTA), amongst others. Whilst ensuring sustainable benefits from furthering economic integration remains a priority, ${ }^{2}$ whether such benefits will continue to be realised is the subject of growing inquiry.

This paper reviews the literature and statistics on Vietnam's socio-economic performance during 2000-18, then draws out implications for policy reforms to leverage the benefits of economic integration. The paper will refrain from analysing the contribution of policies such as those on labour, land, and the environment to socio-economic performance.

Section 2 briefly overviews the process of trade and investment liberalisation in Vietnam. Section 3 provides background information on Vietnam's socioeconomic performance during 2000-18. Section 4 reviews the literature on major impacts of trade and investment liberalisation on the economy. Section 5 recommends policy changes.

\section{Overview of trade and investment liberalisation in Vietnam}

Since Doi Moi, Vietnam has gradually opened the economy to foreign trade and investment. Economic integration had four milestones.

DOI: $10.4324 / 9781003138501-9$ 
First, Vietnam joined the Association of Southeast Asian Nations (ASEAN) in 1995 and the ASEAN Free Trade Area in 1996. By August 2019, Vietnam was signatory to an array of FTAs under the ASEAN Plus framework. At the end of 2015, Vietnam joined the ASEAN Community. As of August 2019, Viet Nam had been active in negotiating the Regional Comprehensive Economic Partnership (RCEP), between ASEAN and China, the Republic of Korea (henceforth, Korea), Japan, Australia, New Zealand, and India.

Second, Vietnam negotiated and signed the Vietnam-United States (US) bilateral trade agreement in 2000, which induced Vietnam to prepare for regional FTA-based integration and the World Trade Organization (WTO) process and gave Vietnam better access to the US, its largest export market, implying improved competitiveness relative to other major exporters.

Third, Vietnam became a member of the WTO in January 2007. The greatest pressures under the WTO are related to institutional reforms and the service sector (CIEM, 2013). To fulfil its WTO commitments, Vietnam had to amend or promulgate many laws, ordinances, and decrees related to domestic institutional regulations.

Fourth, since 2008, Vietnam has focused on bilateral and plurilateral FTAs. It negotiated and/or signed, amongst others, the Economic Partnership Agreement with Japan and FTAs with the EU, Chile, Korea, and the Eurasian Economic Union. Whilst the Trans-Pacific Partnership Agreement (TPP), signed in 2016, could not proceed due to the US's withdrawal, Vietnam signed the CPTPP in March 2018 and ratified it in November 2018. Figure 9.1

\section{Overview of Vietnam's socio-economic performance in 2000-18}

This section focuses on gross domestic product (GDP), trade, investment, macroeconomic stability, and social aspects.

\subsection{Gross domestic product}

The dramatic opening of the economy undoubtedly contributed to rapid GDP growth and explosion of trade from the early 1990s until 2008 (Abbott, Bentzen and Tarp, 2009). In 1998-1999, Vietnam experienced the first bitterness resulting from economic integration as its growth was arrested by the Asian financial crisis. Because economic integration was modest, the effect of the crisis came later for Vietnam than for other more integrated economies (Tran 1999). Growth recovered momentum in 2000 and the country experienced its fastest growth, from $6.8 \%$ in 2000 to $7.1 \%$ in 2007 (Figure 9.2).

Soon after optimism was induced by WTO accession, GDP growth began to slow: $5.7 \%$ in 2008 and $5.4 \%$ in 2009 , with a short-lived recovery to $6.4 \%$ in 2010 and deceleration in 2011-12. GDP growth has been recovering since 2013 , however, reaching $6.7 \%$ in $2015,6.8 \%$ in 2017 , and $7.1 \%$ in 2018 . 

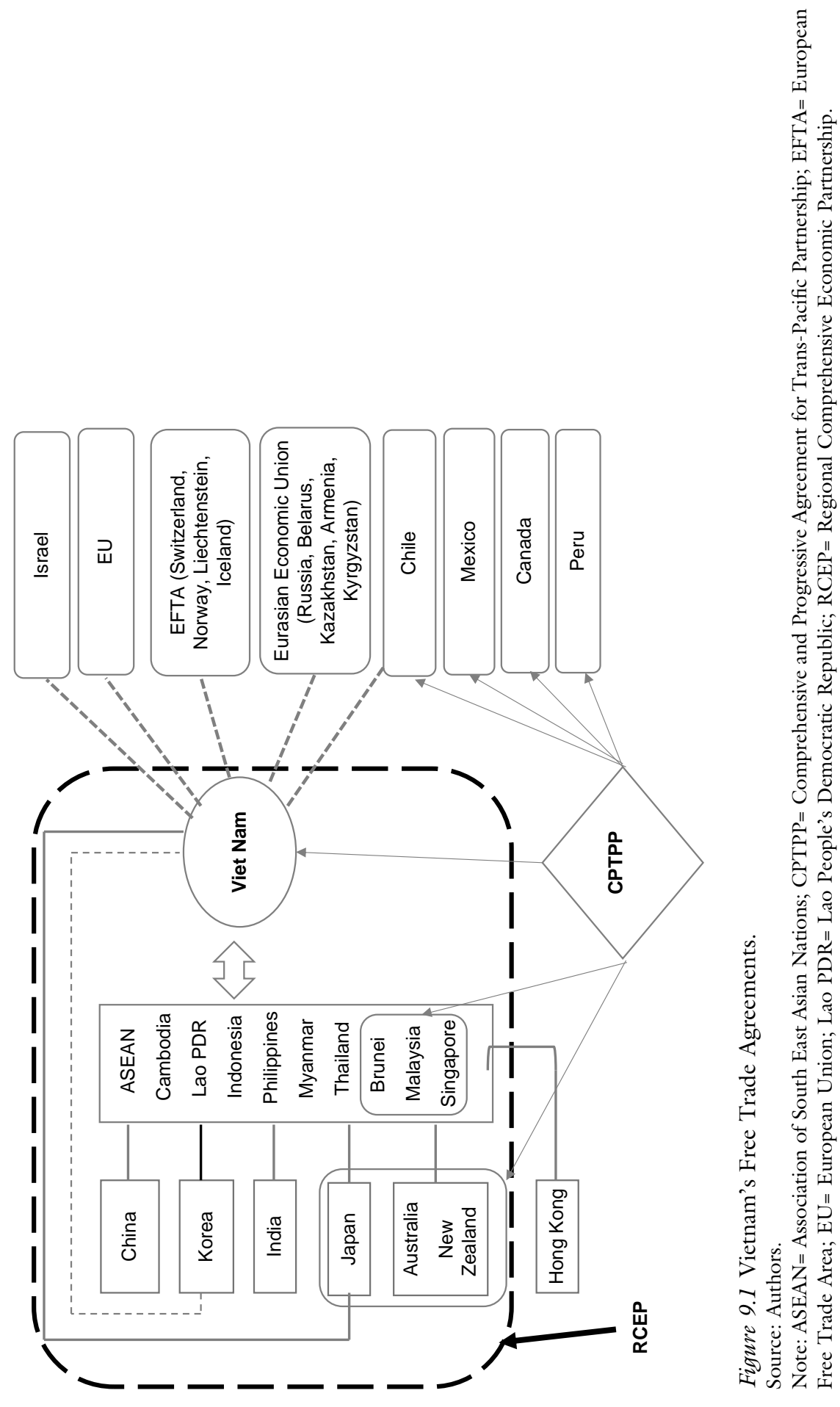


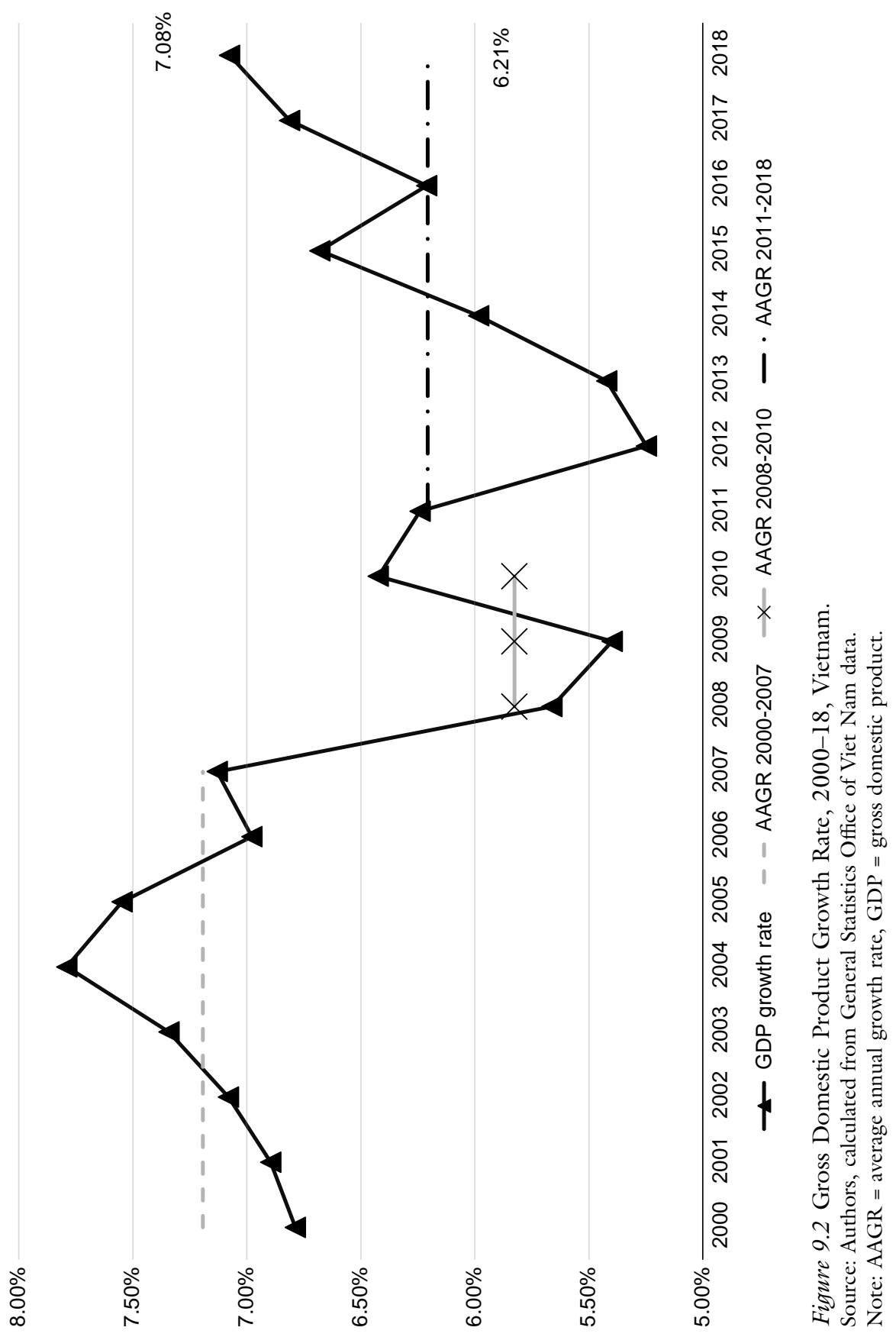




\subsection{Trade}

Following WTO accession, trade increased almost continuously, except in 2009 (Figure 9.3), in value and percentage of GDP. In 2017, the sum of exports and imports reached around 200\% of GDP, higher than in 2007 (154\%) and 2000 (111\%). Merchandise exports grew on average by more than $19.4 \%$ a year during 2000-06. Exports weakened sharply in 2009 amidst the global financial crisis but rebounded strongly in 2010 .

The growth of imports clearly overwhelmed the increase in exports shortly after WTO accession (CIEM, 2013). Consequently, the trade deficit widened to over US\$18.0 billion in 2008, compared with US\$14.2 billion in 2007 and US $\$ 5.1$ billion in 2006. After the global financial crisis, import growth decelerated and the trade deficit contracted to US\$9.8 billion in 2011 .

The years since 2012 exhibited different patterns of export and import growth. Export growth gradually recovered to $21.9 \%$ in 2017 and $13.2 \%$ in 2018 (CIEM 2018,2019 ) whilst import growth has been generally slower. During 2012-18 (except 2015), Vietnam enjoyed a trade surplus, with a record level of US\$6.8 billion in 2018 (Figure 9.3).

Export growth seems to be largely and consistently contributed by foreignowned enterprises. The linkage between foreign-invested enterprises and local counterparts improved slowly. Therefore, export activities had to rely significantly on imported inputs (Vo et al., 2017). Table 9.1

The technology intensity in exports and imports improved over time (Table 9.2). The share of high-technology products in exports rose remarkably from $5.6 \%$ to $37.7 \%$ over 17 years. However, various export products still depended heavily on technology and/or imported materials, so the content of domestic value added was small (Truong et al, 2011; Tran et al., 2011; Vo et al., 2017; Ministry of Planning and Investment, 2018).

The key markets accounted for the lion's share of Vietnam's exports, which averaged $78.46 \%$ in $2002-07$ and $77.29 \%$ during $2011-18$ (Table 9.3). Notable increases in export share can be seen in the cases of China and Korea.

Similarly, the total share of imports from major markets ranged from $75.84 \%$ in 2008-10 to $79.89 \%$ in 2011-18 (Table 9.4). In 2011-18, China ranked first amongst seller of Vietnam's imports, followed by Korea and ASEAN. Notably, the Vietnam- Korea FTA has significantly induced imports from Korea since 2016 and diverted imports from other countries (CIEM, 2018, 2019).

\subsection{Investment}

Foreign direct investment (FDI) inflows have increased since 2001 but boomed only after Vietnam joined the WTO (Figure 9.4). Registered FDI capital exploded from 2007 to 2010, seemingly unaffected by the global recession of 2008-09. Since 2011, Vietnam has experienced a down cycle in registered foreign investment but the figure is still larger than in the pre-WTO period. 


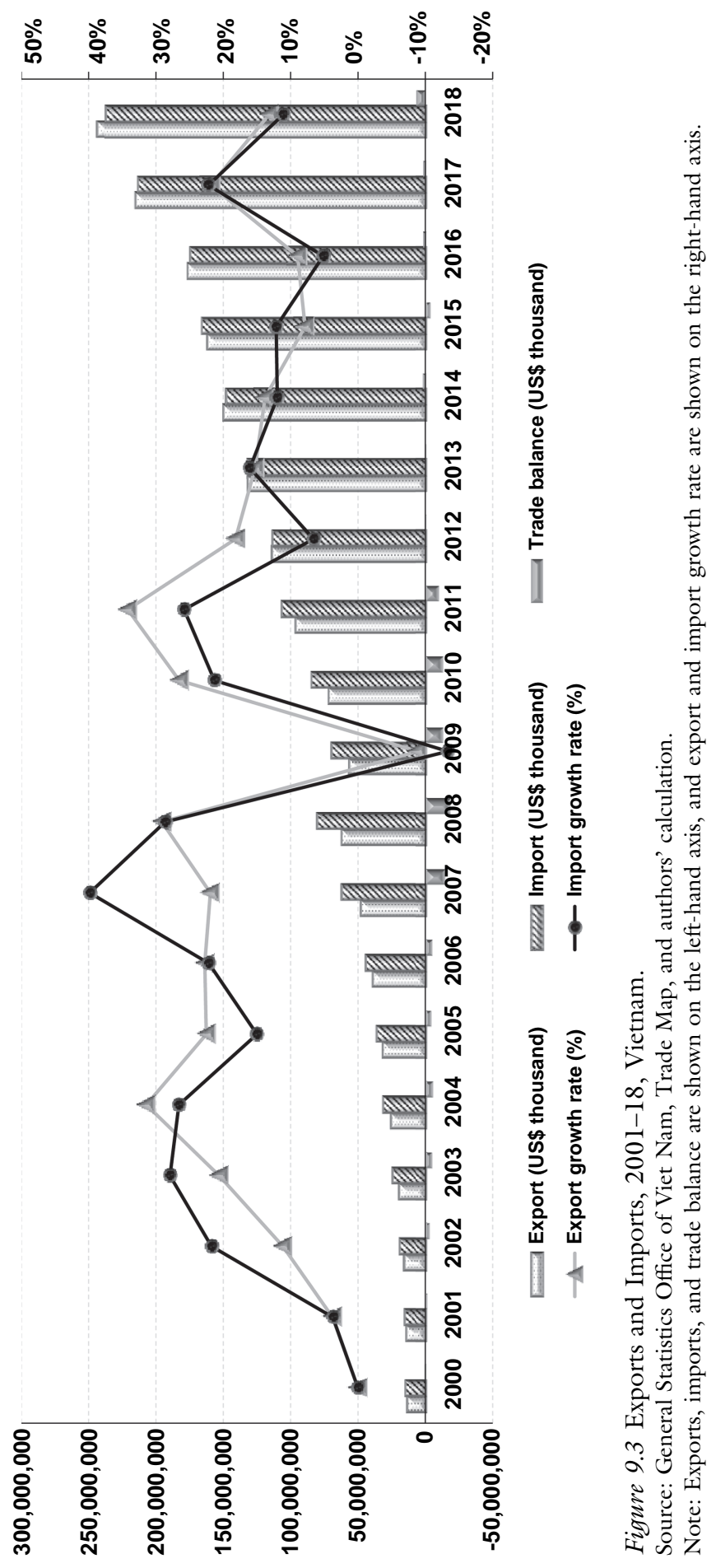


Table 9.1 Exports and Imports by Ownership, Vietnam

\begin{tabular}{llllll}
\hline & \multicolumn{2}{c}{ Share (\%) } & & \multicolumn{2}{c}{ Growth Rate (\%) } \\
\cline { 2 - 3 } \cline { 6 - 7 } & $2008-10$ & $2011-18$ & & $2008-10$ & $2011-18$ \\
\hline Exports & 100 & 100 & & 14.3 & 16.4 \\
FDI enterprises & 48.5 & 65.5 & & 7.0 & 22.4 \\
Domestic enterprises & 51.5 & 34.5 & & 22.8 & 8.3 \\
Imports & 100 & 100 & & 11.7 & 13.7 \\
FDI enterprises & 39.0 & 57.1 & & 19.6 & 18.3 \\
Domestic enterprises & 61.0 & 42.9 & & 6.9 & 8.9 \\
\hline
\end{tabular}

Source: Authors' calculations based on data from the General Department of Viet Nam Customs and the General Statistics Office of Viet Nam.

$\mathrm{FDI}=$ foreign direct investment.

Implemented FDI capital exhibited important changes after WTO accession. Whilst implemented FDI was relatively modest until 2006, it went up to US\$10 billion-US\$12 billion per year during 2007-13. Implemented FDI then increased continuously, reaching US\$19.1 billion in 2018. The share of FDI in gross investment increased from $14.9 \%$ in 2007 to $23.4 \%$ in 2018 .

FDI was initially concentrated in oil and gas exploitation or construction, then moved rapidly to light and heavy industries. FDI was predominant in services; transportation and telecommunications; construction; and real estate (hotels and tourism, offices and apartments, infrastructure) (Tran and Dinh, 2013). Of the 76 countries and territories with investment projects in Vietnam in 2018, the top 5 in terms of registered capital are in Asia (Japan, Korea, China, Singapore, and Hong Kong), accounting for $74.5 \%$ of total registered capital (CIEM, 2019).

\subsection{Macroeconomic stability}

After WTO accession, Vietnam gradually learned to systematically ensure macroeconomic stability. In 2007 and early 2008, Vietnam was still inexperienced in dealing with the impacts of price hikes in international markets as well as in managing huge inflows of capital (Vo and Nguyen, 2009; CIEM, 2010, 2013). Bold and comprehensive measures to control inflation were identified in early 2008 but quickly replaced by policies to prevent economic downturn in the fourth quarter of 2008 - just 2 months after inflation peaked (CIEM, 2011, 2010b; Vo, 2015). As high inflation returned in 2011 after economic stimulus, Vietnam realised that it required bolder and more consistent measures to stabilise the macroeconomic environment in line with economic restructuring (CIEM, $2013,2018,2019)$. Inflation started to go down starting in 2012. In general, inflation has been more stable since 2012 than during 2007-11 (Figure 9.5).

Government budget revenues have been increasing continuously. During 2007-18, inflation-adjusted budget revenues rose by $6.9 \%$ per annum on average. The tax base was significantly improved, particularly in 2007-11 
Trade and Investment Liberalisation 221

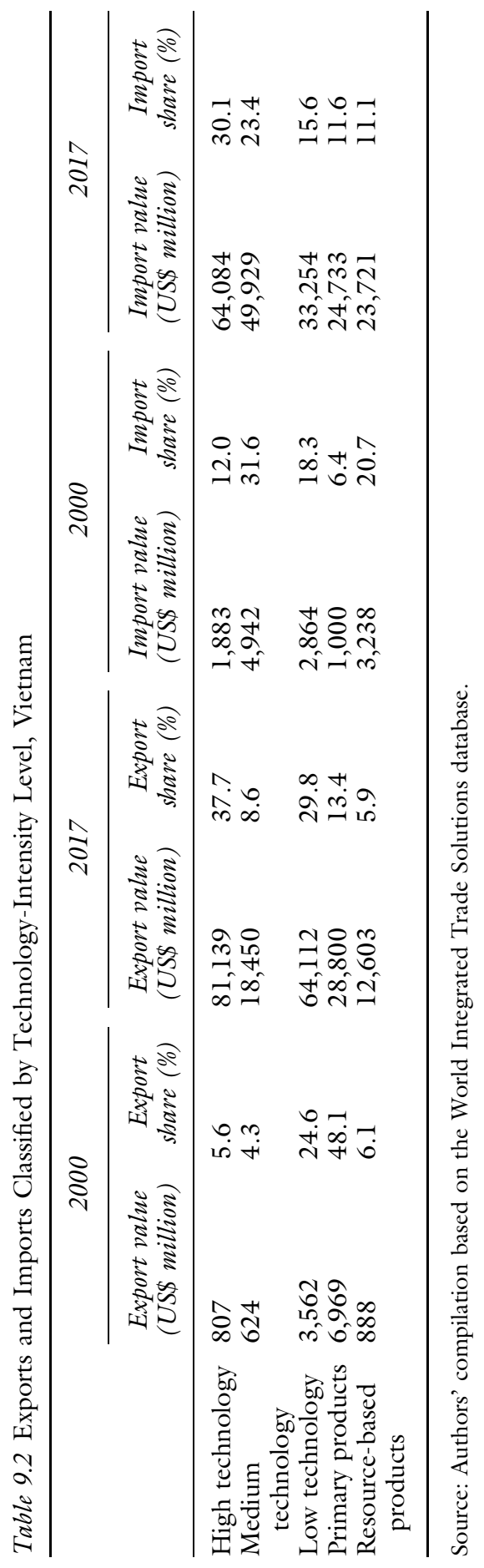


Table 9.3 Export Structure and Export Average Growth Rates, by Major Destination, Vietnam

\begin{tabular}{|c|c|c|c|c|c|c|}
\hline \multirow[t]{2}{*}{ Exports } & \multicolumn{3}{|c|}{ Share (\%) } & \multicolumn{3}{|c|}{ Growth Rate (\%) } \\
\hline & $2002-07$ & $2008-10$ & $2011-18$ & 2002-07 & $2008-10$ & $2011-18$ \\
\hline ASEAN & 16.12 & 15.34 & 11.69 & 21.24 & 8.52 & 11.49 \\
\hline China & 8.92 & 9.37 & 13.00 & 17.05 & 28.54 & 23.26 \\
\hline $\begin{array}{l}\text { European } \\
\quad \text { Union } 28\end{array}$ & 18.56 & 16.55 & 18.15 & 19.21 & 7.77 & 17.68 \\
\hline Japan & 13.33 & 11.73 & 9.05 & 15.92 & 8.26 & 11.79 \\
\hline $\begin{array}{c}\text { Republic of } \\
\text { Korea }\end{array}$ & 2.34 & 3.63 & 6.01 & 20.50 & 35.49 & 24.81 \\
\hline United States & 19.17 & 19.57 & 19.39 & 45.50 & 12.12 & 16.25 \\
\hline Total & 78.46 & 76.19 & 77.29 & & & \\
\hline
\end{tabular}

Source: General Statistics Office of Viet Nam, Trade Map, and authors' calculations.

Table 9.4 Import Structure and Import Average Growth Rates, by Major Destination, Vietnam

\begin{tabular}{|c|c|c|c|c|c|c|}
\hline \multirow[t]{2}{*}{ Imports } & \multicolumn{3}{|c|}{ Share (\%) } & \multicolumn{3}{|c|}{ Growth Rate (\%) } \\
\hline & $2002-07$ & $2008-10$ & $2011-18$ & $2002-07$ & $2008-10$ & $2011-18$ \\
\hline ASEAN & 25.44 & 21.14 & 15.03 & 24.99 & 1.04 & 8.61 \\
\hline China & 15.78 & 22.44 & 27.74 & 41.16 & 16.71 & 15.82 \\
\hline $\begin{array}{l}\text { European } \\
\quad \text { Union } 28\end{array}$ & 8.27 & 7.56 & 6.39 & 21.84 & 7.36 & 10.24 \\
\hline Japan & 11.02 & 10.50 & 8.66 & 18.97 & 13.36 & 9.77 \\
\hline $\begin{array}{c}\text { Republic of } \\
\text { Korea }\end{array}$ & 9.68 & 10.19 & 17.47 & 18.93 & 22.25 & 21.88 \\
\hline United States & 2.82 & 4.01 & 4.61 & 26.69 & 30.51 & 16.42 \\
\hline Total & 73.01 & 75.84 & 79.89 & & & \\
\hline
\end{tabular}

Source: General Statistics Office of Viet Nam, Trade Map, and authors' calculations.

(CIEM, 2013). The ratio of budget revenues to GDP, however, increased slightly from $20.5 \%$ in 2000 to $26.6 \%$ in 2008 , then fell to $25.6 \%$ in 2018 . Revenues from trade accounted for a smaller share in budget revenues (Table 9.5). Vietnam then had to rely more on other domestic taxes, particularly corporate income tax (Nguyen, Tran, and Le, 2018).

Vietnam has been running a prolonged budget deficit. Budget expenditures have kept expanding and remained in excess over budget revenues. Total expenditures (adjusted for inflation) rose on average by $5.8 \%$ per annum in 2007-18. The ratio of budget expenditures to GDP climbed from $28.7 \%$ in 2005 to $32.0 \%$ in 2007 , then trended downwards to $29.1 \%$ in 2018. Vietnam has provided an increasing share of expenditures from the 


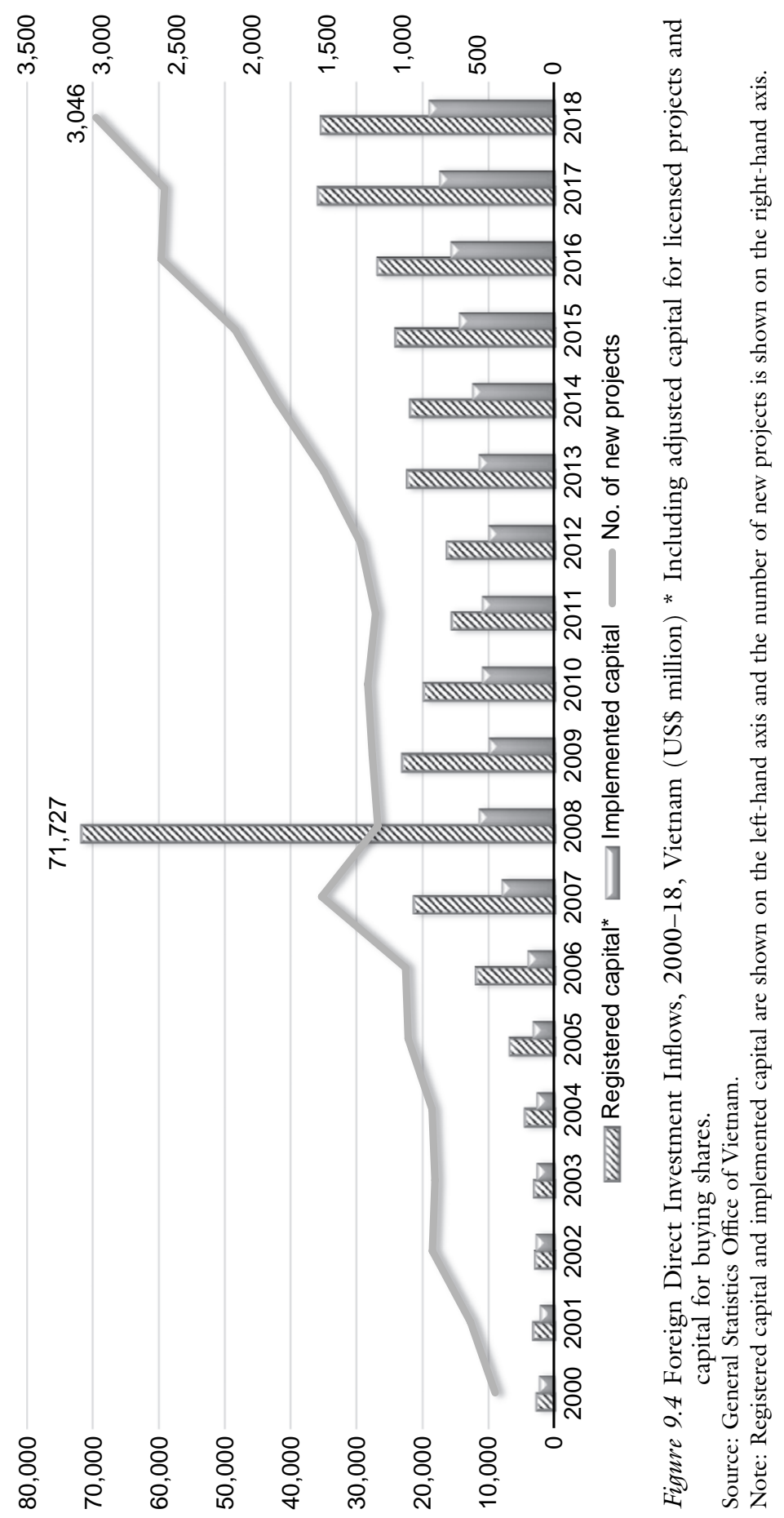


224 Thanb Tri Vo et al.

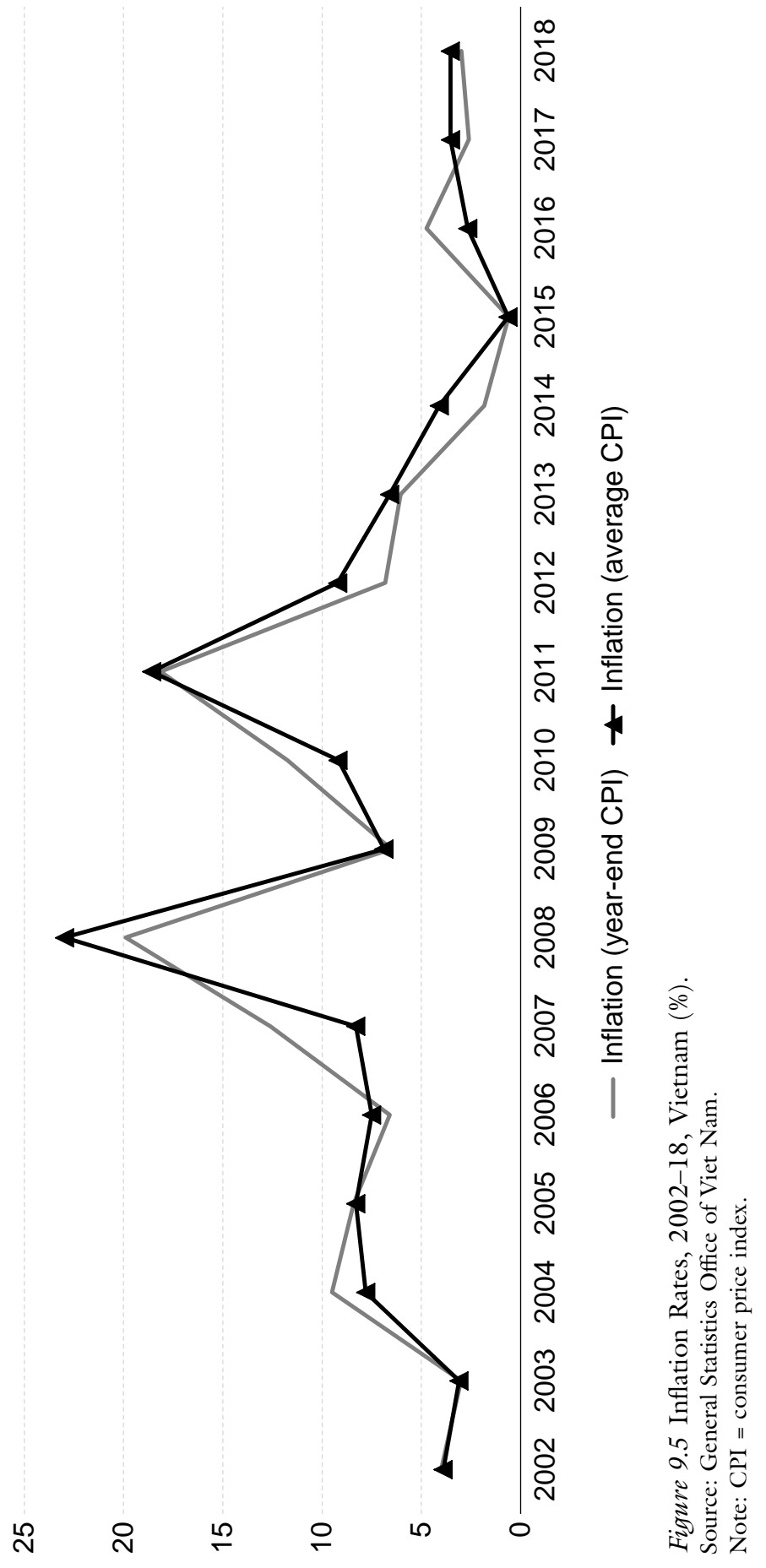


Table 9.5 Structure of Budget Revenues, 2000-18, Vietnam (\%)

\begin{tabular}{lllllllllll}
\hline & 2000 & 2007 & 2008 & 2009 & 2010 & 2011 & 2015 & 2016 & 2017 & 2018 \\
\hline $\begin{array}{c}\text { Revenues } \\
\text { from trade }\end{array}$ & 20.9 & 19.1 & 21.2 & 23.2 & 22.2 & 21.6 & 17.0 & 15.5 & 15.4 & 13.9 \\
$\begin{array}{c}\text { Revenues } \\
\text { from } \\
\text { crude oil }\end{array}$ & 25.9 & 24.4 & 20.8 & 13.4 & 11.8 & 15.3 & 6.8 & 3.6 & 3.8 & 4.0 \\
$\begin{array}{c}\text { Proceedings } \\
\text { from land }\end{array}$ & 3.1 & 10.7 & 9.1 & 9.6 & 9.5 & 8.4 & 8.6 & 11.4 & 12.0 & 10.8 \\
$\begin{array}{c}\text { Personal } \\
\text { income tax }\end{array}$ & 2.0 & 2.3 & 3.0 & 3.1 & 4.5 & 5.3 & 5.7 & 5.9 & 6.1 & 7.2 \\
$\begin{array}{c}\text { Other } \\
\text { revenues }\end{array}$ & 48.1 & 43.4 & 45.9 & 50.6 & 52.1 & 49.4 & 62.0 & 63.5 & 62.6 & 64.1 \\
\hline
\end{tabular}

Source: Authors' calculations from data of the General Statistics Office of Viet Nam and the Ministry of Finance.

Note: As of May 2019, Vietnam had finalised budget figures up to 2016. Figures for 2018 are from the first estimate by the Ministry of Finance.

state budget for education and training, health, and pension and social security. Table 9.6

\subsection{Social aspects}

With a human development index (HDI) of 0.694 in 2017, Vietnam is in the high average group, ranking 116th out of 189 countries (similar to its rank in 2016). Vietnam still lags behind other Asia-Pacific countries. In 1990, Vietnam's HDI was $8.1 \%$, lower than the average of the East Asia-Pacific region; this gap decreased to $4.7 \%$ in 2008 but had widened to $5.3 \%$ by 2017 , arguably because other countries in the region were achieving better results in human development, especially in education (United Nations Development Programme UNDP, 2018).

Education is one sector where Vietnam has achieved the most impressive success in reaching the Millennium Development Goals (MDGs). The literacy rate reached $98.1 \%$ in the $15-35$ age group and $96.83 \%$ in the $15-60$ age group, according to the Ministry of Education and Training report on academic year 2015-16. Vietnam also participated in the Programme for International Student Assessment (PISA) test and scored higher than predicted by the country's income level (Glewwe et al., 2017).

Vietnam continues to reduce poverty. As of 2018, the poverty rate was $6.8 \%$, lower than for 2006 (15.5\%), but income inequality has been widening, partly because of high economic growth over the past 2 decades. The large increase in inequality was seen at the beginning of the 2000s and declined only marginally in the course of the decade (Multilateral Trade Assistance Project MUTRAP, 2015a). The Gini index declined from 37 in 2002 to 35.3 in 2016 following the removal of tariff protection. Figure 9.6 


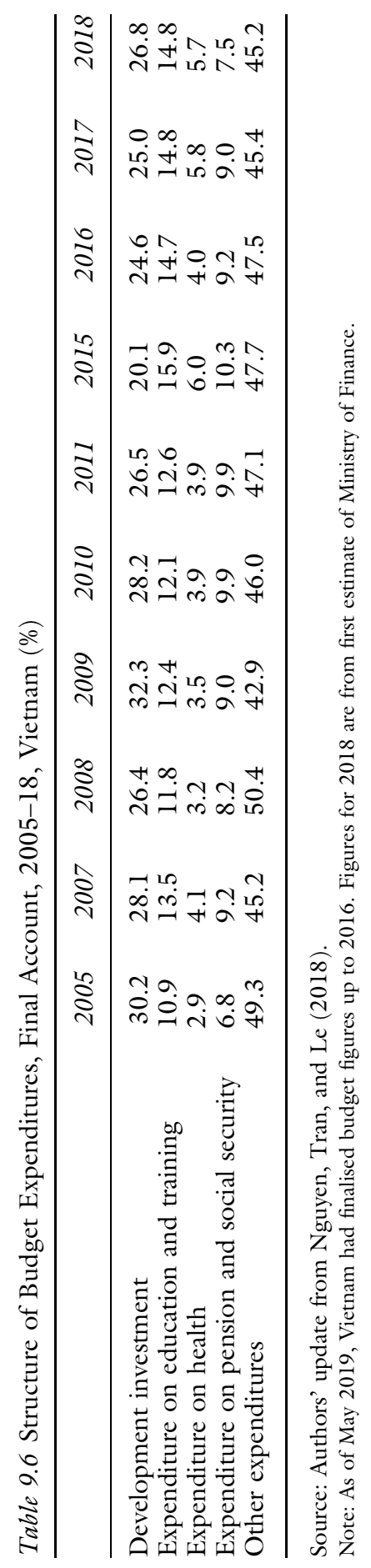




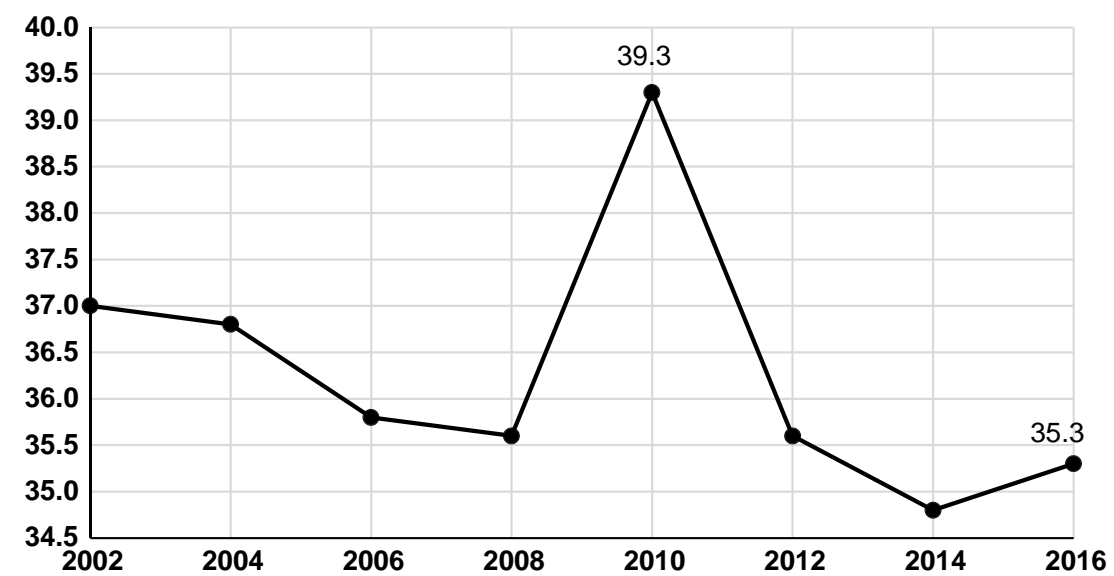

Figure 9.6 Vietnam's Gini Index.

Source: Knoema.

The Global Gender Gap Index 2017 ranked Vietnam 69th out of 144 countries, whilst the United Nations Development Programme (UNDP) Gender Inequality Index gave Vietnam a score of 0.304 . Vietnam was ranked 97 th out of 144 countries in terms of female ratio in political system (Vietnamnet, 2018). The gender pay gap still exists in many areas (World Bank, 2018b).

\section{Major impacts of trade and investment liberalisation on Vietnam's economy}

The literature on impacts of trade and investment liberalisation on Vietnam's economy is extensive. The assessments are ex ante and ex post, and qualitative and quantitative. This section surveys the economic and social aspects of the assessment results.

\subsection{Economic impacts}

The literature on economic impacts often focuses on imports, exports, real wages, employment, investment, and tariff revenues. Various quantitative studies also examine welfare, a measure of real income, to see expected and real improvements due to trade and investment liberalisation. This paper surveys only impacts on welfare, trade, and investment.

Vietnam's impressive GDP growth performance in 2007 was affected by internal and external factors. First, the implementation of a series of important WTO accession commitments to open the internal market has helped Vietnam offer a more predictable business environment for trade and foreign investment (CIEM, 2010, 2013). Second, after Vietnam joined the WTO, enterprises have 
benefited from a lower cost of accessing and expanding to international markets, whilst enjoying more equal treatment in trade and dispute settlement. Such lower costs have resulted from domestic economic reforms parallel to negotiation for WTO accession since 2000. This effect was observed by Roland-Holst et al. (2002) and ex-post confirmed by Vo and Nguyen (2009). Third, Viet Nam continued to appeal to foreign investment thanks to sustained political and socioeconomic stability (CIEM, 2010, 2013).

Following the optimism induced by WTO accession, GDP growth slowed largely because of (i) the rapid and drastic impact of the global financial crisis and economic downturn as Vietnam's economic integration deepened (CIEM, 2013), and (i) the lagged effect of tightening macroeconomic policies to curb inflation in the first half of 2008 (CIEM, 2013; Vo and Nguyen, 2009). In the fourth quarter of 2008, Vietnam had to change its policy stance to prevent economic downturn. Economic growth then exhibited a short-lived recovery in 2010 to $6.4 \%$ due to massive fiscal stimulus: the stimulus package of $8.7 \%$ of GDP helped increase GDP growth rate by only 1.0-1.5 percentage points (CIEM, 2011).

Since 2011, Vietnam has embarked on consistent macroeconomic stabilisation (Vo, 2015; CIEM, 2013), which enables domestic economic restructuring in line with FTA negotiation and implementation. Vanzetti et al. (2011) estimate from various Global Trade Analysis Project simulations that FTAs with China, Japan, and Korea would provide the greatest potential gains in absolute terms for Vietnam, whereas FTAs with Australia, New Zealand, and India would generate little. The benefits from all ASEAN FTAs with Viet Nam in 2012 were estimated at $3 \%$ of the 2007 base national income. Nevertheless, GDP growth decelerated in 2011-12 and only recovered in 2013 , reaching $6.7 \%$ in $2015,6.8 \%$ in 2017 , and $7.1 \%$ in 2018 . Whilst this recovery was largely due to reforms in the domestic business environment (CIEM, 2018, 2019), it should be noted that market and investor confidence also rose due to Vietnam's preparation for mega FTAs (TPP/CPTPP, EVFTA, and RCEP). In light of this, Vietnam's growth potential can be improved after 2019, with FTAs being instrumental.

Various studies attempt to quantify the benefits of new-generation FTAs on Vietnam's economy, all using computable general equilibrium models. Nguyen et al. (2014) estimate that welfare gains from RCEP may amount to US\$227 million-US\$2,239 million. Baker et al. (2017) document expected gains from the EVFTA of US\$3.2 billion in 2020, US\$6.7 billion in 2025, and US\$7.2 billion in 2030 compared with the baseline. The World Bank (2018a) estimates that the CPTPP may increase Vietnam's GDP in 2030 by $1.1 \%$ under the modest scenario and by $3.5 \%$ under the productivity-enhancing scenario. A caveat: all ex-ante quantitative studies before WTO accession underestimated the impact of institutional changes and capital flows induced by integration attempts (CIEM, 2013). Such underestimation may be inherent in the literature on impacts of new-generation FTAs (e.g. Vo, 2015, World Bank, 2018b). 
Post-reform economic growth was accompanied by trade liberalisation reforms that led to an explosion in international trade (Abbott and Tarp, 2012; CIEM, 2013). Nguyen et al. (2018) use constant market share decomposition to show that enhanced competitiveness, as measured by the residual, accounted for around $65.1 \%$ of the export increase in 2014 relative to 2006 . This share is significantly higher than corresponding figures for 2004-07 (Vo and Nguyen, 2011) and for 2006-10 (Nguyen et al., 2018). Thanks to various FTAs, including the TPP/CPTPP and EVFTA, and domestic business environment reforms since 2016 , export growth recovered to $21.9 \%$ in 2017 and $13.2 \%$ in 2018 (CIEM, 2018, 2019).

However, Vietnam's export growth post-WTO fails to compensate for several issues. First, export growth seems to be largely and consistently contributed by foreign-owned enterprises, whilst domestic enterprises have failed to take advantage of integration-induced export opportunities (Vo and Nguyen, 2011; CIEM, 2015; World Bank, 2015; Nguyen et al., 2018; CIEM, 2019). The enhanced competitiveness explained by Nguyen et al. (2018) appears to be largely induced by the presence of major foreign-invested enterprises. The ability of domestic firms to move up in global value chains is limited, trapping them in low value-added production stages (World Bank, 2016b). Second, the linkage between foreign-invested enterprises and local counterparts improved slowly. Whilst motorcycles and electronics, amongst a few other products, have enhanced the capacity of local supporting industries, most sectors still have poor linkages between foreign and local firms (Ministry of Planning and Investment, 2018). Such poor linkages have led to only modest improvement in the domestic value-added content of exports (Tran et al., 2011; Vo et al., 2017). Third, despite the range of FTAs, the use of preferential treatment under them is limited and the extent of FTA utilisation has not significantly improved (Vo and Nguyen, 2015; WTO Center, 2019).

The export structure is shifting from traditional sectors, where Vietnam enjoyed comparative advantage, towards new ones, whose comparative advantage is still unknown (CIEM, 2013, 2017, 2019). Exports continue to shift away from raw materials and towards manufacturing and processing (Truong et al., 2011; Nguyen et al., 2014; Nguyen et al., 2017).

Whilst adding much-needed capital, foreign investment has boosted exports. Using macroeconomic data and error-correction models, Nguyen et al. (2018) and Vo and Nguyen (2011) show that a rise in implemented FDI disbursement tends to increase exports, and the increase is larger in the long term than in the short term. The greater long-term impact is due to FDI spillover effects on exports of other domestic enterprises. In the same manner, when additional employment generated indirectly by FDI in domestic firms is included, we should find an even greater contribution of FDI to total employment.

Linkages between FDI and domestic firms remain weak. Transfer of technology and knowledge by FDI to the nearly 1,500 enterprises in Vietnam was limited at the sectoral level (United Nations Industrial Development Organization UNIDO, 2012). FDI enterprises mainly depend on imported intermediate goods and raw 
materials, whilst linkages with domestic supply chains were not established (Multilateral Trade Assistance Project MUTRAP, 2015b;Ministry of Planning and Investment, 2018). Newman et al. (2013) claim that domestic firms had more productivity spillovers from joint ventures than wholly foreign-owned firms, yet such spillovers are unexplained in the sense that they cannot be attributed to real technology transfers between firms. However, it seems that the WTO and FTAs fail to encourage foreign firms to enhance linkages with domestic counterparts: the finding by Newman et al. (2013) appears to differ from the significant spillover effect during 2003-07 found by Hoang and Pham (2010).

Vietnam's exports exhibited high complementarity with import demand of major markets such as ASEAN, EU, Japan, Korea, the US, and China (Truong et al., 2011; Nguyen et al., 2014; CIEM, 2016). Some argue that high export concentration in selected markets is risky and propose that Vietnam diversify its export markets (Truong et al., 2011; CIEM, 2016). The wide range of FTAs since 2010 clearly reflects that approach. However, whilst creating trade, the new FTAs also significantly divert Vietnam's exports (e.g. World Bank, 2018a). Notable increases in export shares can be seen in the cases of China and Korea (Table 9.3).

Until 2011, the increase in imports was mainly due to (i) income effect as consumers had higher income (Vo and Nguyen, 2009; CIEM, 2010; CIEM, 2013); and (ii) higher demand for imported spare parts and materials for exports (Vo et al., 2017; Tran et al., 2011). Using an error-correction model, Truong et al. (2011) estimated that WTO accession led to a short-term increase of import growth by almost 2.4 percentage points and a long-term increase by 3.4 percentage points. Amongst the key reasons for slower import growth since 2011 were economic restructuring and control of public investment to help stabilise the macroeconomic environment, which reduced import demand (Nguyen et al., 2017). Besides, Vietnam had become better at using more non-tariff measures, which had the effect of reducing imports (Vo et al., 2017; Nguyen et al., 2019).

The boom in registered capital of FDI can be partly attributed to improved confidence of investors in Vietnam's post-WTO growth potential (Vo and Nguyen, 2011; CIEM, 2013). From 2011 onwards, Vietnam experienced a down cycle in registered foreign investment, but the figure is still larger than in the pre-WTO period. More important, implemented capital was stable until 2013 and has increased steadily since 2014 due to (i) increasing opportunities for foreign investors from FTAs with Vietnam (CIEM, 2015, 2018); and (ii) efforts by the government, ministries, and localities to improve the investment and business environment (CIEM, 2018, 2019).

The studies using ex-ante and ex-post quantitative analyses of impacts on the economy are subject to several limitations. These analyses have to assume that any agreement will be implemented as designed, but non-tariff measures may prevent further meaningful liberalisation in implementing existing and future FTAs (Nguyen et al., 2014). Some tariff peaks may be prohibitive, which may cause the overstatement of projected gains from tariff reform. Finally, the ex-post studies, however technically rigorous, could not entirely separate the impacts of trade and liberalisation from those due to other policies within Vietnam. 
Nguyen et al. (2014) identify several limitations of the computable general equilibrium model employed in various studies (such as Nguyen et al. 2014, World Bank 2018a, Baker et al. 2017). First, some changes in production and consumption behaviours are assumed to be automatic responses to tariff changes (and thus relative prices), whilst some practical factors that may affect FTA utilisation are ignored. Second, the model can hardly incorporate impacts of institutional improvement and foreign capital flows. Third, the scenarios are useful to the extent that they help focus on the impacts of FTAs, whilst the actual nontrade policy settings may not be entirely consistent with such scenarios.

\subsection{Social impacts}

Whilst contributing to economic development, deeper economic integration made way for social progress by (i) enhancing economic opportunities and (ii) increasing people's capacity to use them (Vo and Nguyen, 2006; United Nations Development Programme UNDP, 2006). Vietnam, however, still has a bigger human development gap relative to other countries in the region, which have made more progress, especially in education (United Nations Development Programme UNDP, 2018).

Vietnam continues to reduce poverty even as it deepens economic integration. Well before WTO accession, the Centre for International Economics (2002, cited in Abbott et al., 2009) documented the beneficial effects of trade liberalisation on poverty under all scenarios, the results being valid for poverty incidence and poverty gap. Following WTO accession, poverty reduction progressed even with upward adjustment of the national poverty line (Vo, 2014; CIEM, 2013; Nguyen, Tran, and Le, 2018). Still, the new-generation FTAs may contribute to more sustainable reduction of poverty. Compared with the traditional quantitative analyses that rely only on macroeconomic variables, recent studies have utilised household data to simulate impacts at the micro level. Using macro-micro simulation, the World Bank (2018a) projects that CPTPP may help reduce the number of poor people (at the poverty line of US $\$ 5.50 /$ day) by 0.5 million in 2030 compared with the baseline. Using a similar method, Baker et al. (2017) shows that the potential impacts of EVFTA on the poverty rate are favourable but not sizeable: 197,000 people may escape poverty in 2030 thanks to implementation of the agreement, compared with the baseline.

Amongst the reasons for progressive poverty reduction is the continued provision of social security after WTO accession. When hit by the global financial crisis, Vietnam incorporated a substantial social security programme to help disadvantaged groups. The programme includes unemployment insurance, preferential treatment for vulnerable groups, social relief, and support to the poor under government fiscal stimulus packages, amongst others (CIEM, 2010; Vo, 2014). Contingent support against climate change and natural disasters has been ensured by the state and other organisations such as ActionAID International Vietnam (Nguyen et al., 2011). Even though government revenues from trade have decreased, budget expenditures on education, health, and social security have not been pruned (Le et al., 2016). 
Using micro data in macro-micro simulation, the literature shows that new FTAs such as CPTPP and EVFTA may contribute to income inequality. Baker et al. (2017) project a modest increase of the Gini index in 2020, followed by a fall in 2025 and then a rise again in 2030 in the case of EVFTA implementation compared with the baseline scenario. Such results, however, assume that there will be no effect from the reaffirmation of Vietnam and the EU of International Labour Organization conventions and declarations on the rights of workers.

Whilst the gender pay gap still exists in many areas (World Bank, 2018b), Vietnam can hope that it will narrow. Female labour may be paid more than men in such areas as food, manufacturing, textiles, apparel, beverages and tobacco, motor vehicles and transport equipment, minerals, sugar, and other crops (Baker et al., 2017).

\section{New liberalisation context and policy recommendations}

\subsection{New liberalisation context}

\section{a. International context}

First, international economic integration continues, albeit on a bumpier road. Whilst the Doha Development Agenda has stalled, FTAs may liberalise trade and investment but also challenge and destabilise the multilateral trading system. WTO statistics as of September 2019 show that there were 481 notifications by members, including of 302 regional trade agreements remaining in force. Some large-scale FTA agreements have been concluded (such as the EU-Japan FTA, US-Canada-Mexico Agreement, CPTPP), are under negotiation (such as the RCEP), or are under consideration (such as the Asia-Pacific FTA).

Second, the world and especially Asia-Pacific have yet to encounter traditional and nontraditional risk. Territorial disputes occur not only on land but also on the sea. Competition for and cooperation on power and water resources are complicated and affect world supply and prices. Adjustments in food security policy in some economies may lead to hunger and poverty in the region and the world in the absence of a concrete and collaborative framework for inclusive growth.

Third, the global and regional value chains span many countries and economies, especially in Asia-Pacific and particularly Southeast Asia (Baldwin, 2016; Iliuteanu, 2016; Ing and Kimura, 2017; West, 2018; World Bank, 2019). The establishment and development of industry clusters and chains give rise to intense competition in the context of globalisation (Donahue et al., 2018). The division of labour is more intensive and production restructuring is shifted from developed to developing countries to utilise cheap labour in production segmentation that is labour-intensive (for example, from China and Thailand to other countries in Southeast Asia [Intercedent Asia Pte Ltd, 2017]).

Fourth, handling the contagion effect or interaction between economies becomes complicated in the context of international integration. The instability and 
internal economic problems of Vietnam's partners (such as public debt and institutional restructuring in Europe, economic downturn in Japan and China) can cause an array of problems. Protectionism is increasing significantly in a number of economies, including Vietnam's major economic partners (Productivity Commission, 2017; Pacific Economic Cooperation Council PECC, 2018). The trade war between the US and China has cast further doubt on the prospects of the global economy and trade (International Monetary Fund IMF, 2019).

Fifth, the fourth industrial revolution has achieved technological breakthroughs in many core areas such as information and communication technology, energy, and transportation. Traditional large-scale production can take advantage of economies of scale. Cheaper production costs per unit can be achieved because the industrial revolution produces many products that meet specific demand, such as 3D printing, and develops new materials (World Economic Forum, 2017). Participation or non-participation in the industrial revolution can significantly affect the comparative advantage of countries, including Vietnam.

\section{b. Domestic context}

First, Vietnam has become a middle-income country. With the rise of a middleincome class (Berrou et al., 2018; Swedish Trade \& Invest Council, 2018), consumer behaviour and demand for industrial products can be changed. Specifically, demand for high-quality products increases. Consumers are not only interested in the quality of a commodity but also in the services related to it.

Second, the macroeconomic environment was significantly more stable in 2016-18 than in 2011-15 (CIEM, 2018, 2019). Vietnam has more favourable conditions to implement reforms, especially of the microeconomic foundation. Vietnam needs to restructure the economy to shift growth towards improving quality, efficiency, and competitive capacity (CIEM, 2019).

However, the space to manipulate macroeconomic policy is more limited than before 2010. The space to conduct trade policy in support of domestic stakeholders is smaller in the context of FTAs (Vo et al., 2015). Public and government debts are close to their ceilings, increasing interest payments from the state budget and restricting capacity to borrow (CIEM, 2015, 2019). The ability to cope with adverse changes in the domestic economy depends to a large extent on whether Vietnam can retain and increase the space to conduct macroeconomic policies (Nguyen et al., 2019).

Third, Vietnam is quickly leaving the 'golden demographic structure.' Labour growth is on a significant downwards trend. Ageing in Vietnam is fast (Nguyen, 2016; World Bank, 2016a). Vietnam may risk falling into the 'middle-income trap' ( $\mathrm{PwC}, 2017)$ and find it difficult to escape from the economic paradigm that has relied heavily on cheap and low-tech labour.

Fourth, Vietnam needs to focus on improving enterprises' competitiveness. Competitiveness in some traditional products is either slowly improving or significantly degraded. Development of competitive capacity in new products is still 


\section{Thanh Tri Vo et al.}

slower than expected. Many enterprises lack the patience, vision, aspiration, initiative, and motivation to participate in regional and global value chains.

Fifth, natural resources are being gradually depleted, whilst efficiency of use has not increased significantly. Negative impacts on the environment, especially climate change due to economic development and urbanisation, are becoming more noticeable. Changes in production conditions and the environment have negative effects on agriculture development and food security.

Sixth, Vietnam should tackle the risks of integration failure. Pressure from integration becomes more apparent when Vietnam has to remove tariffs on industrial products from ASEAN and as provided by FTAs with other countries. Utilising export preferences in partners' markets is not easy if Vietnam does not meet the rules of origin and other aspects such as labour standards, environmental protection, and corporate social responsibility. Without a strong supporting industry, Viet Nam risks losing opportunities to participate in industrialisation (Ministry of Planning and Investment, 2018).

\subsection{Policy recommendations}

First, notwithstanding deeper economic integration, Vietnam can do more than just depend solely on the global trade environment (Vo et al., 2017). Effective economic integration requires more than just efforts by firms to enhance their competitiveness; instead, the government of Vietnam should assume an equivalent role in accelerating reforms for a more favorable business environment. Unnecessary regulatory burden on business activities should be reduced and transparency and regulatory and policy predictability increased, which should go beyond streamlining non-tariff measures.

Policies to enhance competitiveness, especially to promote FDI, should be implemented. Measures to selectively attract FDI inflows should be enforced ${ }^{3}$ whilst sudden changes (even reversals) of capital flows, especially short-term ones, should be managed. Cost-effective hard and soft infrastructure should be developed to reduce the cost of production and doing business.

Second, Vietnam should leverage the learning effect in post-WTO trade policy, particularly in identifying and penetrating fast-growing markets and regions. Strategic analysis of potential markets and regions is essential. Whilst such strategic analysis - however rigorous - cannot be error-free, the extent and cost of errors can be minimised with meaningful consultation with the business community, including foreign investors. Deepening trade relations with existing partners via new, higher-quality FTAs will generate more value for Vietnam. ${ }^{4}$

The design of FTAs and their harmonisation requirements should be determined beforehand irrespective of whether the arrangements will deliver expost benefits or not. Path dependence should be carefully considered. The benefits of FTAs may be reversed if commitments under them are inconsistent or developed without sequential consideration.

Third, information on the broad international economic integration agenda and on the content of each FTA before it is completed and signed should be 
disseminated. The relevance and timeliness of information are even more important as international and regional economic integration become more uncertain. More active dissemination of information will help ensure that the government gains the trust of the business community, which has a practical policy-relevant perspective.

\section{Notes}

1 Vietnam started implementing the CPTPP on 14 January 2019.

2 Reaffirmed in Resolution 06-NQ/TW by the Steering Committee of the Communist Party of Vietnam in November 2016.

3 Such selective attraction cannot violate WTO rules and principles (especially the most-favoured nation principle). Whilst allowing FDI in a range of sectors, Vietnam should encourage it in strategic, priority industries.

4 For an impact assessment of RCEP on Vietnam's economy, see Nguyen et al. (2014).

\section{References}

Abbott, P. and F. Tarp (2012), 'Globalization Crises, Trade and Development in Vietnam', Journal of International Commerce, Economics and Policy, 03(01), 1240006. World Scientific Publishing Co. Pte. Ltd.

Abbott, P., J. Bentzen, and F. Tarp (2009), 'Trade and Development: Lessons from Vietnam's Past Trade Agreements', World Development, 37(2), pp.341-353.

Baker, P., D. Vanzetti, T.L.H. Pham, C.T. Tran, T.X.T. Nguyen, and A.D. Nguyen (2017), Impact Assessment EU-Vietnam FTA. Activity EU-2, funded by Mutual Trade Assistance Project (MUTRAP).

Baldwin, R. (2016), 'GVC Revolution and Trade Policy'. https://piie.com/system/ files/documents/baldwin20160614ppt.pdf (accessed 23 May 2019).

Berrou, J.P., M. Clement, F. Combarnous, D. Darbon, K.S. Le, and E. Rougier (2018), 'Should We Call It Middle Class?' Economic and Political Stakes of the Middle Income Group Expansion in Vietnam', AFD Research Papers Series, No. 2019-94, Agence Française de Développement.

CIEM (2010), Comprehensive Evaluations of Vietnam's Socio-Economic Performance 3 Years after Accession to the WTO. Ha Noi: Finance Publishing House.

CIEM (2011), Viet Nam's Economy in 2010. Ha Noi: Finance Publishing House.

CIEM (2013), Comprehensive Evaluations of Vietnam's Socio-Economic Performance 5 Years after Accession to the WTO. Ha Noi: Finance Publishing House.

CIEM (2015), Macroeconomic Report for Q4 and 2014. Ha Noi: Finance Publishing House. English and Vietnamese.

CIEM (2016), Macroeconomic Report for Q4 and 2015. Ha Noi: Finance Publishing House. English and Vietnamese.

CIEM (2018), Macroeconomic Report for Q4-2017. Ha Noi: Finance Publishing House. English and Vietnamese.

CIEM (2019), Macroeconomic Report for Q1-2018. Ha Noi: Finance Publishing House. English and Vietnamese.

Donahue, R., J. Parilla, and B. McDearman (2018), 'Rethinking Cluster Initiatives'. Brookings Institute. https://www.brookings.edu/wp-content/uploads/2018/ 
07/201807_Brookings-Metro_Rethinking-Clusters-Initiatives_Full-report-final.pdf (accessed 23 April 2019).

General Department of Vietnam Customs (2018), 'Statistical Data'. https:// www.customs.gov.vn/Lists/ThongKeHaiQuan/Default.aspx (accessed February 2019). Vietnamese.

General Statistics Office of Vietnam (GSO) (2018), Statistical Data. Ha Noi: GSO. www.gso.gov.vn (accessed February 2019). Vietnamese.

Glewwe, P., H.A. Dang, J. Lee, and K. Vu (2017), 'What Explains Vietnam's Exceptional Performance in Education Relative to Other Countries?' Analysis of the 2012 and 2015 PISA Data. https://www.apec.umn.edu/sites/apec.umn.edu/ files/pisa_vn4.pdf (accessed 22 May 2019).

Grossman, G.M. and A.B. Krueger (1991), 'Environmental Impacts of North American Free Trade Agreement', Discussion Papers in Economics, No. 158. Princeton, NJ: Woodrow Wilson School of Public and International Affairs.

Hoang, V.T., and T.H. Pham (2010), 'Chapter 7: Productivity Spillovers from Foreign Direct Investment: The Case of Vietnam', in C.H. Hahn and D. Narjoko (eds.), Causes and Consequences of Globalization in East Asia: What Do the Micro Data Analyses Show? Jakarta: Economic Research Institute for ASEAN and East Asia.

Iliuteanu, M.A. (2016), 'Deepening and Expanding Global Value Chain Participation across Asia and Europe'. http://www.eria.org/Deepening_and_Expanding_GVC_ Participation.pdf (accessed 12 February 2019).

Ing, L.Y. and F. Kimura (2017), Production Networks in Southeast Asia. New York: Routledge Publishing House.

Institute of labour Science and Social Affairs (ILSSA) (2018), Labour and Social Trends in Viet Nam 2012-2017. Hanoi: Labour Publishing House.

Intercedent Asia Pte Ltd (2017), Asia Corporate Strategy Assessment: 10 Trends in Corporate Strategic Planning for the Asian Region. https://www.roihu.com/ wp-content/uploads/2017/05/Tekes-Asia-corporate-strategy-assessment.pdf (accessed 23 May 2019).

International Monetary Fund (IMF) (2019), World Economic Outlook Update: A Weakening Global Expansion. Washington, DC: IMF.

Knoema. https://knoema.com/atlas/Viet-Nam/GINI-index (accessed 3 April 2019).

Le, M.S., T. Singh, and D.T. Nguyen (2016), Trade Liberalisation and Poverty: Vietnam Now and Beyond. New York, NY: Routledge Publishing House.

Ministry of Planning and Investment (2018), 'Đánh giá tình hình các doanh nghiệp sản xuất sản phẩm phụ kiện đầu vào cung cấp cho các doanh nghiệp đầu tư nước ngoài tại các tỉnh/thành phố trực thuộc Trung ương' [An Assessment of Suppliers of Inputs for Foreign-Invested Firms in Cities, Provinces directly under the Central Government, Report to the Government of Viet Nam]. Vietnamese.

Multilateral Trade Assistance Project (MUTRAP) (2015a), 'Assessing the Socio-Economic Preparedness of Vietnam Towards ASEAN Economic Community'. Activity: ICB-1.

Multilateral Trade Assistance Project (MUTRAP) (2015b), 'Assessing the Impacts of the Regional Comprehensive Economic Partnership on Vietnam's Economy'. Activity: ICB-8.

Newman, C., J. Rand, T. Talbot, and F. Tarp (2013), 'Technology Transfers, Foreign Investment and Productivity Spillovers: Evidence from Vietnam'. http:// www.ciem.org.vn/Portals/1/CIEM/IndepthStudy/TCS12_Technology_Transfer_ Final.pdf (accessed 22 May 2019). 
Nguyen, A.D. (2018), 'Efforts to Foster Vietnam-Japan Investment Cooperation since 2008'. Presentation at the Annual CIEM-Toshiba International Foundation Workshop on Deepening Bilateral Cooperation After 10 Years of Vietnam-Japan Economic Partnership Agreement, Ha Noi, 15 November.

Nguyen, A.D., T.H. Dinh, T.N.T. Do, and T.T. Vo (2019), 'Non-tariff Measures in Viet Nam', in H.T.T. Doan and S. Rosenow (eds.), Non-tariff Measures in ASEAN - An Update. Jakarta: Economic Research Institute for ASEAN and East Asia (ERIA), pp.207-233.

Nguyen, A.D., T.Q. Le, B.M. Tran, and H.T. Nguyen (2011), 'Review of Country Strategy Paper for 2006-2010 of ActionAID International Vietnam’. Report for ActionAID International Vietnam.

Nguyen, A.D., D.C. Nguyen, T.T. Vo, B.M. Tran, T.H. Pham, and H.L. Le (2017), 'Việt Nam tham gia các hiệp định thương mại tự do mới: Một số yêu cầu cải cách thể chế thương mại và đầu tư' [Impacts of New-Generation FTAs and Institutional Reforms in Vietnam]. Funded by the Australian Department for Foreign Affairs and Trade project, Restructuring for a Competitive Vietnam. Vietnamese.

Nguyen, A.D., B.M. Tran, and M.A. Le (2018), 'Viet Nam VNMOD vl.0 (2012-17)'. Southmod Project Country Report. https://www.wider.unu.edu/ sites/default/files/Publications/Report/PDF/SOUTHMOD-Viet-Nam-2018V1.0.pdf (accessed 6 November 2019).

Nguyen, A.D., D. Vanzetti, R. Trewin, T.H. Dinh, T.H. Vu, and X.S. Le (2014), 'Assessing Impacts of Regional Comprehensive Economic Partnership on Vietnam's Economy. Activity: ICB-8 (Output 3)'. Funded by the Mutual Trade Assistance Project (MUTRAP).

Nguyen, A.D., T.T. Vo, and T.N.T. Do (2018), 'Vietnam's Exports After Joining the WTO'. Unpublished paper.

Nguyen, B.N. (2018), 'The Transition Process of Vietnam's Trade Policy from Closed Economy to "Servicification" Economy', Studia i Prace WNEiZ US, 53, pp.295-310.

Nguyen, D.C., A.D. Nguyen, B.M. Tran, T.H. Dinh, H.L. Le, and T.H. Pham (2019), 'Giải pháp tăng cường sức chống chịu của nền kinh tế Việt Nam' [Measures to Improve Economic Resilience of Viet Nam]. Report for Aus4Reform Project. Vietnamese.

Nguyen, H. (2017), 'Vietnam Macro - Analysis of BOP', Viet Capital Security. https://www.vcsc.com.vn/userfiles/others/MacroThougtPiece--20170531.pdf (accessed 5 January 2018).

Nguyen, T.H. (2007), 'The Impact of Globalisation on Higher Education in China and Vietnam: Policies and Practices'. Presented at a conference, Education in a Changing Environment, University of Salford, 12-14 September.

Nguyen, T.H. (2009), Marketization of Higher Education in Vietnam in the Era of Neoliberal Globalization: Policy and Practice. Master's thesis. Burnaby, Canada: Simon Fraser University.

Nguyen, T.T.A. (2005), Impact of FDI on Economic Growth in Vietnam. Hanoi: Science and Technics Publishing House. Vietnamese and English.

Nguyen, V.H. (2016), Population Aging in Vietnam. (accessed 2 February 2019) https://wapes.org/en/system/files/vietnamp2g3.pdf

Pacific Economic Cooperation Council (PECC) (2018), 'State of the Region 2018-2019'. https://www.pecc.org/resources/regional-cooperation/2584-state-ofthe-region-2018-2019 (accessed 05 March 2019). 
Petri, P.A. and L.K.P. Phan (2015), Viet Nam Bets on Trade: The Implications of the TPP, EVFTA and RCEP Agreements. Hanoi: United Nations Development Programme.

Productivity Commission (2017), 'Rising Protectionism: Challenges, Threats and Opportunities for Australia'. Research paper.

PwC (2017), 'Spotlight on Vietnam: The Leading Emerging Market'. October. https://www.pwc.com/vn/en/publications/2017/spotlight-on-vietnam.pdf (accessed 02 January 2018).

Roland-Holst, D., F. Tarp, V.A. Dinh, T.T. Vo, L.H. Pham, \& H.M. Dinh (2002). 'Vietnamas Accession to the World Trade Organization: Economic Projections to 2020', Discussion Papers in Economic Policy Analysis, No. 0204.

Swedish Trade \& Invest Council (2018), 'Capturing the Vietnamese Consumer Market'. Business Sweden. https://www.business-sweden.se/contentassets/c53 a2f46ffl44ld4adbelf0dal40a5ad/vietnam-consumer-goods-point-of-view.pdf (accessed 17 April 2019).

Trade Map. http://www.trademap.org/Bilateral_TS.aspx (accessed 28 February 2019).

Tran, B.M., T. Bui, Q.L. Trinh, and V.C. Hoang (2011), 'Ước tính hàm lượng nhập khẩu trong xuất khẩu phục vụ công tác hoạch định chính sách kinh tế ở Việt Nam' [Estimating the Import Content of Exports to Support Policies in Viet Nam]. Ministerial research project. Vietnamese.

Tran, D.T. (1999), 'Impact of the Regional Crisis on the Vietnamese Economy'. http://ismea.org/ASIAlist/Tran-Dinh-Thien.html (accessed 23 April 2019)

Tran, T.A.D. and T.T.B. Dinh (2013), 'FDI and Growth in Vietnam: A Critical Survey', Journal of Economics and Development, 15(3), pp.91-116.

Truong, D.T., T.T. Vo, T.G. Bui, V.C. Phan, T.D. Le, A.D. Nguyen, and S.A. Pham (2011), 'Tác động của cam kết mở cửa thị trường trong WTO và các hiệp định thương mại tự do đến hoạt động sản xuất, thương mại của Việt Nam và các cơ chế hoàn thiện cơ chế điều hành xuất nhập khẩu của Bộ Công Thương giai đoạn 2011-2015' [Impacts of Commitments on Opening the Market under WTO and other Free Trade Agreements on Vietnam's Production and Trade Activities and Mechanism to Improve Import and Export Management Scheme of the Ministry of Industry and Trade in 2011-2015]. Report for Multilateral Trade Assistance Project (MUTRAP). Vietnamese.

United Nations Commodity Trade Statistics Database (UN Comtrade) (2017), 'Metadata \& Reference, Commodity List'. https://comtrade.un.org/db/mr/ rfCommoditiesList.aspx (accessed February 2019).

United Nations Development Programme (UNDP) (2006), South-East Asia Regional Economic Integration and Cooperation Deepening and Broadening the Benefits for Human Development. Colombo: UNDP Regional Centre.

United Nations Development Programme (UNDP) (2018), 'Human Development Indices and Indicators: Viet Nam's 2018 Statistical Update'. https://www.vn. undp.org/content/dam/vietnam/img/undp-vn-hdr-stats-2018.pdf (accessed 6 November 2019).

United Nations Industrial Development Organization (UNIDO) (2012), 'Viet Nam Industrial Investment Report 2011 - Understanding the Impact of Foreign Direct Investment on Industrial Development'. https://www.unido.org/sites/default/ files/2012-08/VIIR\%20print_0.pdf (accessed 12 May 2016).

United Nations Economic and Social Commission for Asia and the Pacific (UNESCAP) (2015), 'Global Value Chains and Interconnectedness of Asia-Pacific 
Economies'. In Asia Pacific Trade and Investment Report 2015, pp.103-138. https://www.unescap.org/sites/default/files/Chapter\%207\%20-\%20GVCs\%20in \%20the\%20Asia-Pacific.pdf (accessed 18 May 2019).

Vanzetti, D., R. Trewin, J. Cassing, D.T. Truong, L.H. Pham, A.D. Nguyen, and Q.L. Le (2011). 'Impact Assessment of Free Trade Agreements on Vietnam's Economy', Activity Code FTA-HOR. Multilateral Trade Assistance Project (MUTRAP).

Vietnamnet (2017), 'Illegal Waste Imports Difficult to Control, Manage: Agencies' https://english.vietnamnet.vn/fms/environment/192031/illegal-waste-importsdifficult-to-control--manage--agencies.html (accessed 25 February 2019).

Vietnamnet (2018), 'Vietnam Expects High-quality FDI Inflows After CPTPP Ratification'. https://english.vietnamnet.vn/fms/business/213125/vietnam-expectshigh-quality-fdi-inflows-after-cptpp-ratification.html (accessed 18 February 2019).

Vietnamnet (2018), 'Vietnam Makes Great Strides in Promoting Gender Equality'. https://en.vietnamplus.vn/vietnam-makes-great-strides-in-promoting-genderequality/143585.vnp (accessed 6 November 2019).

Vietnamnews (2017), 'State Budget Reform Will Be a Testing Process'. http:// vietnamnews.vn/economy/418748/state-budget-reform-will-be-a-testing-process.html\#LAieUwrk7SPR5T4X.99 (accessed 18 February 2019).

Vo, T.T. (2012), 'Achieving an Efficient AEC by 2015: A Perspective from Vietnam', in S.B. Das (ed.), Achieving ASEAN Economic Community 2015: Challenges for Member Countries and Businesses. Singapore: Institute of Southeast Asian Studies, pp.161-177.

Vo, T.T. (2014), 'Making Growth Inclusive: The Case of Vietnam'. Unpublished report for the United Nations Economic and Social Commission for Asia and the Pacific. December.

Vo, T.T. (2015), 'In the Midst of Global Economic Uncertainties: Vietnam's Experience since WTO Accession', in S. Chirathivat, C. Sabhasri, and A. Chongvilaivan (eds.), Global Economic Uncertainties and Southeast Asian Economies. Singapore: ISEAS-Yusof Institute, pp.123-147.

Vo, T.T. (2015), 'Vietnam's Perspectives on Regional Economic Integration', Journal of Southeast Asian Economies, 32(1), pp. 106-124.

Vo, T.T. (2016), 'Country Paper for Viet Nam'. Unpublished report for the United Nations Economic and Social Commission for Asia and the Pacific. February.

Vo, T.T. and A.D. Nguyen (2009), 'Vietnam after Two Years of WTO Accession: What Lessons Can Be Learnt', ASEAN Economic Bulletin, 26(1), pp.15-35.

Vo, T.T. and A.D. Nguyen (2011), 'Revisiting Exports and Foreign Direct Investment in Vietnam', Asian Economic Policy Review, 6, pp.112-131.

Vo, T.T. and A.D. Nguyen (2015), 'Survey of FTA Utilisation in Viet Nam', in L.Y. Ing and S. Urata (eds), The Use of FTAs in ASEAN: Survey-based Analysis. Jakarta: Economic Research Institute for ASEAN and East Asia, pp.271-300.

Vo, T.T. and T. Nguyen (2006), 'Vietnam Human Development 1999-2004: What the Current Data Show?' Unpublished report for the United Nations Development Programme. English and Vietnamese.

Vo, T.T., A.D. Nguyen, and T. Bui (2017), 'Trade in Value Added: The Case of Viet Nam', in L.Y. Ing and F. Kimura (eds), Production Networks in Southeast Asia. New York: Routledge Publishing House, pp.183-201.

Vo, T.T., A.D. Nguyen, and B.M. Tran (2017), 'Non-tariff Measures in Viet Nam', in L.Y. Ing, S. Fernandez de Cordoba, and O. Cadot (eds), Non-tariff Measures in ASEAN. Jakarta: Economic Research Institute for ASEAN and East Asia, pp.155-167. 
Vo, T.T., A.D. Nguyen, B.M. Tran, T.H. Dinh, and D.B. Le (2015), 'Impacts of Current and Proposed FTAs and BITs on Vietnam's Long-Term Development Goals: A Case Study of Food Processing and Electronics Manufacturing Sectors'. Report for ActionAID International Vietnam. July.

VOV (2018), 'Vietnam's GDP Growth Rate in 2018 Highest in 11 Years'. https:// english.vov.vn/economy/vietnams-gdp-growth-rate-in-2018-highest-in-11years-389676.vov (accessed February 2019).

West, J. (2018), 'Global Value Chains in the Asia-Pacific'. https:// asiancenturyinstitute.com/international/1439-global-value-chains-in-theasia-pacific (accessed 12 January 2019).

World Bank (2015), Taking Stock: An Update on Vietnam's Recent Economic Developments. Washington, DC: World Bank.

World Bank (2016a), 'Tiếp bước thành công - Nhóm ưu tiên tăng trưởng toàn diện và bền vững' [Moving Forward - Priority for Inclusive and Sustainable Growth]. http://documents.worldbank.org/curated/en/199441476437862446/pdf/108348VIETNAMESE-PUBLIC-VietnamSCDfinalVNOct.pdf (accessed 23 April 2019).

World Bank (2016b), Vietnam 2035. Towards Prosperity, Creativity, Equity, and Democracy. Washington, DC: World Bank.

World Bank (2018a), Economic and Income Distribution Impacts of the Comprehensive and Progressive Agreement for Trans-Pacific Partnership: The Case of Viet Nam. Hanoi: World Bank. English and Vietnamese.

World Bank (2018b), 'Gender Gap in Earnings in Vietnam: Why Do Vietnamese Women Work in Lower Paid Occupations?'. http://documents.worldbank.org/ curated/en/685791521537975174/pdf/124438-BRI-19-3-2018-11-16-51EAPVietnamBriefWEBv.pdf (accessed 2 May 2019).

World Bank (2019), World Development Report 2020: Global Value Chains - Trading for Development. Washington, DC: World Bank.

World Economic Forum (2017), Impact of the Fourth Industrial Revolution on Supply Chains. Geneva: World Economic Forum.

World Integrated Trade Solution (WITS). (2019). http://wits.worldbank.org/ WITS/WITS/Default-A.aspx?Page=Default (accessed February 2019).

WTO Center (2019), 'Tỷ lệ tận dụng C/O ưu đãi theo các hiệp định thương mại của Việt Nam qua các năm' [Use of Preferential C/O in Viet Nam's FTAs Over Time]. Vietnamese. www.trungtamwto.vn/download/18449/Bang\%20tan\%20dung \%20uu\%20dai\%20FTAs\%20qua\%20tung\%20nam $\% 20$ - \%20VN\%20(updated $\% 202$ 018).pdf (accessed 22 May 2019).

Yen Hai (2015), 'Điểm mới trong Luật Đầu tư và Luật Doanh nghiệp' [New Content in the Investment Law and Enterprise Law]. http://baotintuc.vn/kinhte/diem-moi-trong-luat-dau-tu-va-luat-doanh-nghiep-20150624173730816.htm (accessed 2 May 2019). Vietnamese. 